\title{
MIR124-1 wt Allele
}

National Cancer Institute

\section{Source}

National Cancer Institute. MIR124-1 wt Allele. NCI Thesaurus. Code C82060.

The human MIR124-1 wild-type allele is located in the vicinity of 8p23.1 and is 84 bases in length. This allele, which encodes MIR124-1 RNA, plays a role in many cancers, including lung, colorectal, breast, leukemia, meduloblastoma and glioblastoma multiforme. 